\title{
Effects of Different Concentrations of Selenium on Nutrient Uptake of Wild Vegetable Nasturtium officinale
}

\author{
Hongyan Li ${ }^{1, a}$, Xun Wang ${ }^{1, b}$, Dan Xia ${ }^{2, c}$ and Lijin Lin ${ }^{1, d^{*}}$ \\ ${ }^{1}$ Institute of Pomology and Olericulture, Sichuan Agricultural University, Chengdu, Sichuan, China \\ ${ }^{2}$ College of Chemistry and Life Science, Chengdu Normal University, Chengdu, Sichuan, China

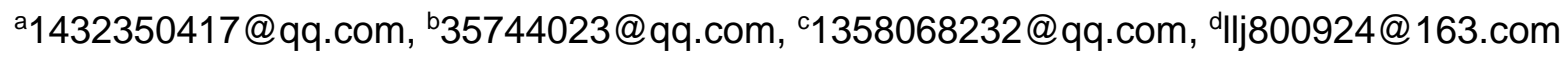 \\ ${ }^{*}$ Corresponding author. Hongyan Li and Xun Wang contributed equally to this work.
}

\begin{abstract}
Keywords: Nasturtium officinale; Selenium stress; Nutrient uptake
Abstract: A pot experiment was carried out to study the effects of different concentrations of selenium on nutrient uptake of wild vegetable Nasturtium officinale. The total nitrogen $(\mathrm{N})$, total phosphorus $(\mathrm{P})$ and total potassium $(\mathrm{K})$ contents in stems, leaves and shoots of $N$. officinale were determined. With the increase of Se concentrations in soil, the total N, P, K contents in shoots of $N$. officinale had the increase trend. So, the treatments of Se promoted the N, P, K absorption of $N$. officinale. These results indicate that adding Se in soil could promote the nutrient absorption of $N$. officinale, which might promote the growth of $N$. officinale.
\end{abstract}

\section{Introduction}

Selenium (Se) is an important trace element in the body's function and plays an extremely important role [1]. For the human body, Se has anti-cancer, to resist a variety of diseases (such as prevention of cardiovascular and cerebrovascular diseases, liver disease, Keshan disease), anti-aging, detoxification, detoxification, enhance immune function and other functions [2-4]. There are different levels of lack of Se in $70 \%$ of the region of China, and different levels of Se intake in $72 \%$ of the population [5]. Se can not be synthesized in the body and must be ingested from food. The Se content in seafood and liver is higher, but in meat and cereals is lower, and in fruits and vegetables is very low [2, 6]. Long-term consumption of high content of Se fish, meat will bring a burden on human digestion, but also to some families to bring some economic pressure, and excessive Se can also cause Se poisoning [3]. Therefore, cheap, fresh and delicious Se-rich vegetables become an important way to supplement the body of Se [7]. The study on the enrichment characteristics of Se in vegetables has been reported, but the higher Se content of vegetables less [7-9], further screening of high Se content of vegetables on the human body to add Se is of great significance.

Wild vegetable is one of vegetables with high nutritional value and health value, and have become popular food at home and abroad [10]. In recent years, the development and utilization of wild vegetable resources and deep processing technology has gradually been the attention of scholars and attention [11]. Nasturtium officinale $\mathrm{R}$. Br. is a perennial cruciferous emergent plant of wild vegetable that is widely distributed in Europe, Asia and North America, and it grows rapidly in nutrient-rich water and is propagated easily from cuttings [12]. In this study, the effects of different concentrations of selenium on nutrient uptake of $N$. officinale were studied. The aim of this study was to screen out the best concentration of Se which could promote the nutrient absorption of $N$. officinale.

\section{Materials and Methods}

Materials. The Inceptisol soil samples (purple soil in the Genetic Soil Classification of China) were collected from the Chengdu campus farm of Sichuan Agricultural University $\left(30^{\circ} 42^{\prime} \mathrm{N}, 103^{\circ} 51^{\prime} \mathrm{E}\right)$ in April 2017. The basic properties of the soil were $\mathrm{pH} 6.94$, organic matter $17.54 \mathrm{~g} / \mathrm{kg}$, total nitrogen $3.63 \mathrm{~g} / \mathrm{kg}$, total phosphorus $0.38 \mathrm{~g} / \mathrm{kg}$, total potassium $17.54 \mathrm{~g} / \mathrm{kg}$, alkali soluble nitrogen 195.00 $\mathrm{mg} / \mathrm{kg}$, available phosphorus $6.25 \mathrm{mg} / \mathrm{kg}$ and available potassium $191.13 \mathrm{mg} / \mathrm{kg}$ [13]. The seedlings of $N$. officinale were collected from a ditch in the Ya'an campus farm in December 2016. 
Experimental Design. The soil samples were air dried and sieved to $5 \mathrm{~mm}$ in October 2016, then $3.0 \mathrm{~kg}$ of the air-dried soil was weighed into polyethylene pots $(15 \mathrm{~cm}$ tall, $18 \mathrm{~cm}$ diameter), and Se was added to the soils as $\mathrm{Na}_{2} \mathrm{SeO}_{3}$ at $0,5,10,25,50,75$ and $100 \mathrm{mg} / \mathrm{kg}$. The soil was maintained in the submerged state, and then the soil in each pot was mixed. The soils were soaked in the Se solution for 4 weeks, and then the soil in each pot was mixed thoroughly. Three uniform N. officinale seedlings (10 cm in length) were transplanted into each pot in December 2016. Each treatment was repeated three times making a total of 21 pots, and put in a completely randomized design with $10 \mathrm{~cm}$ spacing between pots. The water depth was $1 \mathrm{~cm}$ higher than the soil surface in the first two weeks of the experiment, and $5 \mathrm{~cm}$ above the soil surface from two weeks until the time that the $N$. officinale seedlings were harvested.

After 60 days, the $N$. officinale were dug up and divided into stem and leaf, then washed with tap water firstly, followed by deionized water. After that, the organs of all plants were dried at $80{ }^{\circ} \mathrm{C}$ until constant weight, ground to $<0.149 \mathrm{~mm}$, and sealed into plastic bags for the determination of total nitrogen $(\mathrm{N})$, total phosphorus $(\mathrm{P})$ and total potassium $(\mathrm{K})$ contents [14].

Statistical Analyses. Statistical analyses were conducted using SPSS 13.0 statistical software (IBM, Chicago, IL, USA). Data were analyzed by one-way analysis of variance with least significant difference (LSD) at the $\mathrm{p}=0.05$ confidence level.

\section{Results and Discussion}

Total N Contents in N. officinale. With the increase of Se concentrations in soil, the total N contents in stems, leaves and shoots of $N$. officinale had the increase trend, and the treatments of Se promoted the $\mathrm{N}$ absorption of $N$. officinale (Table 1 ). The total $\mathrm{N}$ content in stems of $N$. officinale was ranked as: $100 \mathrm{mg} / \mathrm{kg}>10 \mathrm{mg} / \mathrm{kg}>50 \mathrm{mg} / \mathrm{kg}>75 \mathrm{mg} / \mathrm{kg}>5 \mathrm{mg} / \mathrm{kg}>25 \mathrm{mg} / \mathrm{kg}>0 \mathrm{mg} / \mathrm{kg}$, in leaves of $N$. officinale was $100 \mathrm{mg} / \mathrm{kg}>50 \mathrm{mg} / \mathrm{kg}>75 \mathrm{mg} / \mathrm{kg}>5 \mathrm{mg} / \mathrm{kg}>10 \mathrm{mg} / \mathrm{kg}>25 \mathrm{mg} / \mathrm{kg}>0 \mathrm{mg} / \mathrm{kg}$, and in shoots of $N$. officinale was $100 \mathrm{mg} / \mathrm{kg}>75 \mathrm{mg} / \mathrm{kg}>50 \mathrm{mg} / \mathrm{kg}>10 \mathrm{mg} / \mathrm{kg}>5 \mathrm{mg} / \mathrm{kg}>25 \mathrm{mg} / \mathrm{kg}>0$ $\mathrm{mg} / \mathrm{kg}$. When the soil Se concentrations were 5, 10, 25, 50, 75 and $100 \mathrm{mg} / \mathrm{kg}$, compared with the control, the total $\mathrm{N}$ content in stems of $N$. officinale significantly $(p<0.05)$ increased by $19.75 \%$, $24.15 \%, 16.15 \%, 21.63 \%, 20.91 \%$ and $35.90 \%$, respectively, in leaves of $N$. officinale significantly $(p$ $<0.05$ ) increased by $8.82 \%, 8.54 \%, 8.45 \%, 17.86 \%, 17.42 \%$ and $37.63 \%$, respectively, and in shoots of $N$. officinale significantly $(p<0.05)$ increased by $11.72 \%, 13.81 \%, 10.40 \%, 14.80 \%, 15.61 \%$ and $36.38 \%$, respectively.

Table 1 Total N contents in N. officinale under Se stress

\begin{tabular}{|c|c|c|c|}
\hline Treatments & $\begin{array}{c}\text { Stems } \\
(\mathrm{mg} / \mathrm{g})\end{array}$ & $\begin{array}{c}\text { Leaves } \\
(\mathrm{mg} / \mathrm{g})\end{array}$ & $\begin{array}{c}\text { Shoots } \\
(\mathrm{mg} / \mathrm{g})\end{array}$ \\
\hline 0 & $13.87 \pm 0.73 \mathrm{c}$ & $31.97 \pm 1.31 \mathrm{~d}$ & $22.02 \pm 0.97 \mathrm{c}$ \\
\hline 5 & $16.61 \pm 0.90 \mathrm{~b}$ & $34.79 \pm 1.37 \mathrm{c}$ & $24.60 \pm 1.09 \mathrm{~b}$ \\
\hline 10 & $17.22 \pm 0.80 \mathrm{~b}$ & $34.70 \pm 2.32 \mathrm{c}$ & $25.06 \pm 1.36 \mathrm{~b}$ \\
\hline 25 & $16.11 \pm 0.85 \mathrm{~b}$ & $34.67 \pm 2.18 \mathrm{c}$ & $24.31 \pm 1.27 \mathrm{~b}$ \\
\hline 50 & $16.87 \pm 0.84 \mathrm{~b}$ & $37.68 \pm 2.13 \mathrm{~b}$ & $25.28 \pm 1.39 \mathrm{~b}$ \\
\hline 75 & $16.77 \pm 1.28 \mathrm{~b}$ & $37.54 \pm 2.64 \mathrm{~b}$ & $25.47 \pm 1.75 \mathrm{~b}$ \\
\hline 100 & $18.85 \pm 1.03 \mathrm{a}$ & $44.00 \pm 2.85 \mathrm{a}$ & $30.03 \pm 1.79 \mathrm{a}$ \\
\hline
\end{tabular}

Values are means \pm standard errors. Means with the same letter within each column are not significantly different at $p<0.05$.

Total P Contents in $N$. officinale. With the increase of Se concentrations in soil, the total P contents in stems and shoots of $N$. officinale had the increase trend, and the treatments of Se promoted the $\mathrm{P}$ absorption of $N$. officinale (Table 2). However, the total $\mathrm{P}$ contents in leaves of $N$. officinale had no increase trend with the increase of soil Se concentrations. The total $\mathrm{P}$ content in stems of $N$. officinale was ranked as: $50 \mathrm{mg} / \mathrm{kg}>5 \mathrm{mg} / \mathrm{kg}>75 \mathrm{mg} / \mathrm{kg}>25 \mathrm{mg} / \mathrm{kg}>10 \mathrm{mg} / \mathrm{kg}>100 \mathrm{mg} / \mathrm{kg}>0$ $\mathrm{mg} / \mathrm{kg}$, in leaves of $N$. officinale was $100 \mathrm{mg} / \mathrm{kg}>5 \mathrm{mg} / \mathrm{kg}>0 \mathrm{mg} / \mathrm{kg}>75 \mathrm{mg} / \mathrm{kg}>50 \mathrm{mg} / \mathrm{kg}>25$ 
$\mathrm{mg} / \mathrm{kg}>10 \mathrm{mg} / \mathrm{kg}$, and in shoots of $N$. officinale was $5 \mathrm{mg} / \mathrm{kg}>50 \mathrm{mg} / \mathrm{kg}>100 \mathrm{mg} / \mathrm{kg}>75 \mathrm{mg} / \mathrm{kg}>$ $25 \mathrm{mg} / \mathrm{kg}>10 \mathrm{mg} / \mathrm{kg}>0 \mathrm{mg} / \mathrm{kg}$. When the soil Se concentrations were 5, 10, 25, 50, 75 and 100 $\mathrm{mg} / \mathrm{kg}$, compared with the control, the total P content in stems of $N$. officinale significantly $(p<0.05)$ increased by $41.27 \%, 27.87 \%, 30.16 \%, 46.91 \%, 30.69 \%$ and $22.57 \%$, respectively, respectively, and in shoots of $N$. officinale significantly $(p<0.05$ ) increased by $25.75 \%, 9.21 \%, 11.09 \%, 24.62 \%$, $19.36 \%$ and $21.80 \%$, respectively. When the soil Se concentrations were 5 and $100 \mathrm{mg} / \mathrm{kg}$, the total P contents in leaves of $N$. officinale increased by $2.45 \%(p>0.05)$ and $20.25 \%(p<0.05)$, respectively, compared with the control. When the soil Se concentrations were 10, 25, 50 and $75 \mathrm{mg} / \mathrm{kg}$, the total P contents in leaves of $N$. officinale decreased by $17.28 \%(p<0.05), 16.97 \%(p<0.05), 15.54 \%(p<$ $0.05)$ and $0.20 \%(p>0.05)$, espectively, compared with the control.

Table 2 Total P contents in N. officinale under Se stress

\begin{tabular}{|c|c|c|c|}
\hline Treatments & $\begin{array}{c}\text { Stems } \\
(\mathrm{mg} / \mathrm{g})\end{array}$ & $\begin{array}{c}\text { Leaves } \\
(\mathrm{mg} / \mathrm{g})\end{array}$ & $\begin{array}{c}\text { Shoots } \\
(\mathrm{mg} / \mathrm{g})\end{array}$ \\
\hline 0 & $5.67 \pm 0.38 \mathrm{c}$ & $4.89 \pm 0.27 \mathrm{~b}$ & $5.32 \pm 0.33 \mathrm{c}$ \\
\hline 5 & $8.01 \pm 0.44 \mathrm{a}$ & $5.01 \pm 0.31 \mathrm{~b}$ & $6.69 \pm 0.38 \mathrm{a}$ \\
\hline 10 & $7.25 \pm 0.32 \mathrm{~b}$ & $4.04 \pm 0.22 \mathrm{c}$ & $5.81 \pm 0.26 \mathrm{~b}$ \\
\hline 25 & $7.38 \pm 0.42 \mathrm{~b}$ & $4.06 \pm 0.24 \mathrm{c}$ & $5.91 \pm 0.33 \mathrm{~b}$ \\
\hline 50 & $8.33 \pm 0.44 \mathrm{a}$ & $4.13 \pm 0.26 \mathrm{c}$ & $6.63 \pm 0.36 \mathrm{a}$ \\
\hline 75 & $7.41 \pm 0.50 \mathrm{~b}$ & $4.88 \pm 0.35 \mathrm{~b}$ & $6.35 \pm 0.43 \mathrm{a}$ \\
\hline 100 & $6.95 \pm 0.44 \mathrm{~b}$ & $5.88 \pm 0.36 \mathrm{a}$ & $6.48 \pm 0.40 \mathrm{a}$ \\
\hline
\end{tabular}

Values are means \pm standard errors. Means with the same letter within each column are not significantly different at $p<0.05$.

Total K Contents in $N$. officinale. With the increase of Se concentrations in soil, the total K contents in stems, leaves and shoots of $N$. officinale had the increase trend, and the treatments of Se promoted the $\mathrm{K}$ absorption of $N$. officinale (Table 3). The total $\mathrm{K}$ content in stems of $N$. officinale was ranked as: $100 \mathrm{mg} / \mathrm{kg}>50 \mathrm{mg} / \mathrm{kg}>75 \mathrm{mg} / \mathrm{kg}>5 \mathrm{mg} / \mathrm{kg}>25 \mathrm{mg} / \mathrm{kg}>10 \mathrm{mg} / \mathrm{kg}>0 \mathrm{mg} / \mathrm{kg}$, in leaves of $N$. officinale was $100 \mathrm{mg} / \mathrm{kg}>75 \mathrm{mg} / \mathrm{kg}>5 \mathrm{mg} / \mathrm{kg}>25 \mathrm{mg} / \mathrm{kg}>10 \mathrm{mg} / \mathrm{kg}>50 \mathrm{mg} / \mathrm{kg}>0 \mathrm{mg} / \mathrm{kg}$, and in shoots of $N$. officinale was $100 \mathrm{mg} / \mathrm{kg}>75 \mathrm{mg} / \mathrm{kg}>50 \mathrm{mg} / \mathrm{kg}>5 \mathrm{mg} / \mathrm{kg}>25 \mathrm{mg} / \mathrm{kg}>10$ $\mathrm{mg} / \mathrm{kg}>0 \mathrm{mg} / \mathrm{kg}$. When the soil Se concentrations were 5, 10, 25, 50, 75 and $100 \mathrm{mg} / \mathrm{kg}$, compared with the control, the total $\mathrm{K}$ content in stems of $N$. officinale significantly $(p<0.05)$ increased by $18.25 \%, 16.74 \%, 17.68 \%, 37.52 \%, 28.57 \%$ and $28.80 \%$, respectively, in leaves of $N$. officinale significantly $(p<0.05)$ increased by $18.86 \%, 16.41 \%, 18.09 \%, 9.51 \%, 36.98 \%$ and $47.32 \%$, respectively, and in shoots of $N$. officinale significantly $(p<0.05)$ increased by $18.70 \%, 16.66 \%$, $17.99 \%, 27.98 \%, 32.42 \%$ and $36.51 \%$, respectively.

Table 3 Total K contents in N. officinale under Se stress

\begin{tabular}{|c|c|c|c|}
\hline Treatments & $\begin{array}{c}\text { Stems } \\
(\mathrm{mg} / \mathrm{g})\end{array}$ & $\begin{array}{c}\text { Leaves } \\
(\mathrm{mg} / \mathrm{g})\end{array}$ & $\begin{array}{c}\text { Shoots } \\
(\mathrm{mg} / \mathrm{g})\end{array}$ \\
\hline 0 & $43.50 \pm 1.89 \mathrm{~d}$ & $37.53 \pm 1.43 \mathrm{e}$ & $40.81 \pm 1.67 \mathrm{~d}$ \\
\hline 5 & $51.44 \pm 2.51 \mathrm{c}$ & $44.61 \pm 2.03 \mathrm{c}$ & $48.44 \pm 1.85 \mathrm{c}$ \\
\hline 10 & $50.78 \pm 2.52 \mathrm{c}$ & $43.69 \pm 1.85 \mathrm{c}$ & $47.61 \pm 1.94 \mathrm{c}$ \\
\hline 25 & $51.19 \pm 2.83 \mathrm{c}$ & $44.32 \pm 2.24 \mathrm{c}$ & $48.15 \pm 2.11 \mathrm{c}$ \\
\hline 50 & $59.82 \pm 3.57 \mathrm{a}$ & $41.10 \pm 2.22 \mathrm{~d}$ & $52.23 \pm 2.44 \mathrm{~b}$ \\
\hline 75 & $55.93 \pm 2.96 \mathrm{~b}$ & $51.41 \pm 2.69 \mathrm{~b}$ & $54.04 \pm 2.53 \mathrm{ab}$ \\
\hline 100 & $56.03 \pm 3.64 \mathrm{~b}$ & $55.29 \pm 2.68 \mathrm{a}$ & $55.71 \pm 2.71 \mathrm{a}$ \\
\hline
\end{tabular}

Values are means \pm standard errors. Means with the same letter within each column are not significantly different at $p<0.05$. 


\section{Conclusions}

With the increase of Se concentrations in soil, the total N, P, K contents in shoots of $N$. officinale had the increase trend. So, the treatments of Se promoted the N, P, K absorption of $N$. officinale. These results indicate that adding Se in soil could promote the nutrient absorption of $N$. officinale, which might promote the growth of $N$. officinale.

\section{Acknowledgements}

This work was financially supported by the Application Infrastructure Project of Science and Technology Department of Sichuan Province (2016JY0258).

\section{References}

[1] M.Y. Xia: Acta Nutrimenta Sinica Vol. 35 (2013), p. 223.

[2] B. Wang: Middle-Aged Health Care Vol. 5 (2007), p. 48.

[3] L.Z. Qu, S.J. Yang and S. Gao: Chinese Agricultural Science Bulletin Vol. 26 (2010), p. 94.

[4] H.J. Zhao, P.H. Liu and Q.Y. Sun: Progress in Veterinary Medicine Vol. 28 (2007), p. 96.

[5] L.Y. Shi and S.W. Luo: Journal of Xiangyang Vocational and Technical College Vol. 4 (2005), p. 108.

[6] M. Kohlmeie: Nutrient Metabolism Vol. Suppl (2003), p. 722.

[7] D. Wu, K.M. Fang and H.F. Shen: Acta Agriculturae Jiangxi Vol. 24 (2012), p. 23.

[8] Y. Sang: Transformation of exogenous selenium and iodine in soil and its effect on wild plants, (Northeast Forestry University, 2000).

[9] X.F. Du, Y.X. Wan and Y.H. Wang: Northern Horticulture Vol. 20 (2015), p. 186.

[10]Y.Y. Li, L.H. Huang and X.W. Chen: Chinese Agricultural Science Bulletin Vol. 22 (2006), p. 101.

[11]Y.Y. Li and L.H. Huang: Guangdong Trace Elements Science Vol. 10 (2005), p. 45.

[12]J. Edmondson: Botanical Journal of the Linnean Society Vol. 152 (2006), p. 132.

[13]L. Lin, Q. Jin, Y. Liu, B. Ning, M.A. Liao and L. Luo: Environmental Toxicology and Chemistry Vol. 33 (2014), p. 2422.

[14]S.D. Bao: Agrochemical Soil Analysis (3rd edition, China Agriculture Press, Beijing, China 2000). 